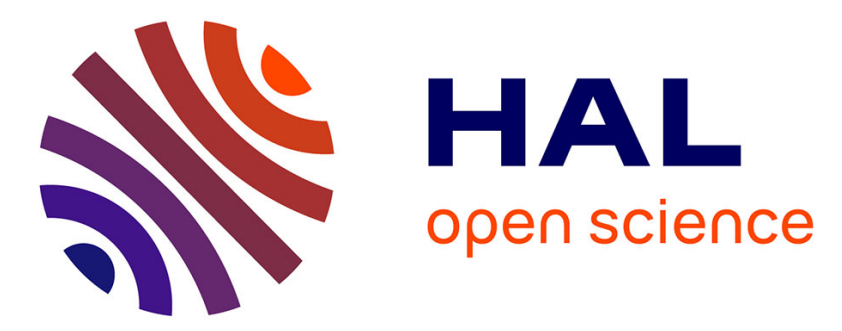

\title{
Evaluation of the Potential of Cobalamin Derivatives Bearing Ru(II) Polypyridyl Complexes as Photosensitisers for Photodynamic Therapy
}

Marta Jakubaszek, Jeremie Rossier, Johannes Karges, Joachim Delasoie, Bruno Goud, Gilles Gasser, Fabio Zobi

\section{To cite this version:}

Marta Jakubaszek, Jeremie Rossier, Johannes Karges, Joachim Delasoie, Bruno Goud, et al.. Evaluation of the Potential of Cobalamin Derivatives Bearing Ru(II) Polypyridyl Complexes as Photosensitisers for Photodynamic Therapy. Helvetica Chimica Acta, 2019, 10.1002/hlca.201900104. hal-02145682

\section{HAL Id: hal-02145682 \\ https://hal.science/hal-02145682}

Submitted on 3 Jun 2019

HAL is a multi-disciplinary open access archive for the deposit and dissemination of scientific research documents, whether they are published or not. The documents may come from teaching and research institutions in France or abroad, or from public or private research centers.
L'archive ouverte pluridisciplinaire HAL, est destinée au dépôt et à la diffusion de documents scientifiques de niveau recherche, publiés ou non, émanant des établissements d'enseignement et de recherche français ou étrangers, des laboratoires publics ou privés. 


\title{
Evaluation of the Potential of Cobalamin Derivatives Bearing Ru(II) Polypyridyl Complexes as Photosensitisers for Photodynamic Therapy
}

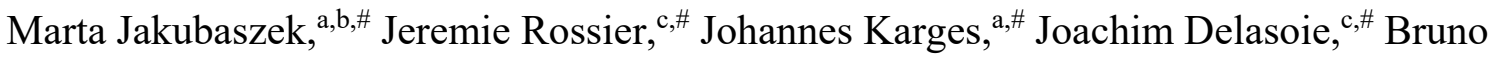 \\ Goud, ${ }^{\mathrm{b}}$ Gilles Gasser, ${ }^{\mathrm{a},{ }^{*}}$ and Fabio Zobi ${ }^{\mathrm{c}, *}$ \\ ${ }^{a}$ Chimie ParisTech, PSL University, CNRS, Institute of Chemistry for Life and Health \\ Sciences, Laboratory for Inorganic Chemical Biology, F-75005 Paris, France, \\ gilles.gasser@chimieparistech.psl.eu \\ ${ }^{\mathrm{b}}$ Institut Curie, PSL University, CNRS UMR 144, Paris, France. \\ ${ }^{\mathrm{c}}$ Chemistry Department, University of Fribourg, CH-1700 Fribourg, Switzerland, \\ fabio.zobi@unifr.ch
}

The current photosensitizers (PSs) for photodynamic therapy (PDT) lack selectivity for cancer cells. To tackle this drawback, in view of selective cancer delivery, we envisioned conjugating two ruthenium polypyridyl complexes to vitamin $\mathrm{B}_{12}$ (Cobalamin, $\mathrm{Cbl}$ ) to take advantage of the solubility and active uptake of the latter. Ultimately, our results showed that the transcobalamin pathway is unlikely involved for the delivery of these ruthenium-based PDT PSs, emphasizing the difficulty in successfully delivering metal complexes to cancer cells.

Keywords: bioinorganic chemistry $\bullet$ cobalamine $\bullet$ medicinal inorganic chemistry $\bullet$ photodynamic therapy $\bullet$ ruthenium polypyridyl complexes

\section{Introduction}

Photodynamic therapy (PDT) is an approved medical technique that relies on the use of a photosensitizer (PS) to ultimately generate reactive oxygen species (ROS) or radicals that can trigger cell death. ${ }^{[1]}$ The interest of this method is its spatio-temporal control. The PS is activated only when and where the physician applies light. In brief, upon irradiation at a specific, defined wavelength, an electron of the ground state of the PS reaches a singlet excited state $\left({ }^{1} \mathrm{PS}^{*}\right)$, which then reaches a triplet state $\left({ }^{3} \mathrm{PS} *\right)$ through an intersystem crossing (ISC) event. ${ }^{[2]}$ The PDT process can then rely on two types of mechanism: 1) in Type I, an electron or proton transfer from the species ${ }^{3} \mathrm{PS} *$ to a biological substrate that generates radicals which can further 
react with molecular oxygen and form superoxides, hydroxyl radicals or peroxides or 2) in Type II, an energy transfer from ${ }^{3} \mathrm{PS} *$ to molecular oxygen in its ground triplet state $\left({ }^{3} \mathrm{O}_{2}\right)$ to generate the highly toxic singlet oxygen $\left({ }^{1} \mathrm{O}_{2}\right) \cdot{ }^{[3]}$

The currently used PSs in the clinic are mainly based on cyclic tetrapyrrolic scaffolds (chlorins, phtalocyanines and porphyrines ${ }^{[4]}$ ). Their main drawbacks are a lack of selectivity towards cancers cells, a low water solubility, an important photobleaching and, sometimes, serious problems of photosensitivity for the treated patients. ${ }^{[5]} \mathrm{Ru}(\mathrm{II})$ polypyridyl complexes were found to be an interesting alternative to the current PDT PSs. Although the use of such compounds as PDT PS against cancer is relatively recent, the results are spectacular with one of such compounds, TLD-1433, having recently completed phase I clinical trial against bladder cancer ${ }^{[2,6-10]}$ We note that to reach the therapeutic window for PDT treatment $(\sim 600$ to 800 $\mathrm{nm}$ ), some Ru(II) polypyridyl complexes were found to be good PSs for two-photon PDT ${ }^{111-}$ 13], further illustrating the versatility of ruthenium in medicinal chemistry. To further improve the properties of the $\mathrm{Ru}(\mathrm{II})$-based PDT PSs, it is also possible to conjugate them with targeting moieties, or to associate them in non-covalent manner with serum or membrane proteins. ${ }^{[14-16]}$ Another possible strategy envisioned by our group and by others is the encapsulation of the $\mathrm{Ru}(\mathrm{II})$-based PDT agents in polymers or their functionalization to nanoparticles. ${ }^{[17-19]}$ Vitamin $\mathrm{B}_{12}$ is a vital nutrient that is characterized by a low bioavailability. Because it is playing an essential role in cell proliferation, it is crucial for fast growing cells. ${ }^{[20]}$ This interesting characteristic was already used in several studies ${ }^{[21]}$ in which cobalamin was used as a targeting moiety for metal complexes to direct them towards fast dividing malignant cells. ${ }^{[22-24]}$ With this in mind, in this work, we aimed at developing a system for improving the solubility and uptake of $\mathrm{Ru}(\mathrm{II})$-based PSs into cancer cells. Our hope was that the resulting conjugates would have a good water solubility and an active cellular uptake. ${ }^{[25,26]}$ Indeed, in the systemic circulation, $\mathrm{Cbl}$ is brought to the cells by a carrier protein named transcobalamin and ultimately taken up following a receptor-mediated endocytosis. ${ }^{[13,27]}$ Therefore, two trisbipyridyl ruthenium(II) complexes were conjugated to vitamin $\mathrm{B}_{12}$ (Cobalamin, $\mathrm{Cbl}$ ). After characterization of the new conjugate $\mathrm{B}_{12}-2$, both molecules were tested in vitro to evaluate their efficiency in PDT as well as their cellular uptake. This data were compared with the $\mathrm{Ru}(\mathrm{II})$ complexes themselves.

\section{Results and Discussion}




\section{Compounds design and chemistry}

As a cofactor, inside cells, cob(III)alamin is ultimately reduced to cob(I)alamin and during this process, the $\beta$-upper ligand of cobalamin becomes labile. ${ }^{[28]}$ This feature has been explored in the past to attach drugs/drug candidates at this position. ${ }^{[29]}$ However, chemical modifications at the $\beta$-position were for a long time restrained by synthetic constraints as well as the instability of the resulting derivatives. ${ }^{[30]}$ Recent advances in organometallic chemistry of cobalamin have allowed to generate stable derivatives and to rethink this prodrug approach. ${ }^{[31,32]}$ As a prerequisite, the chosen compounds should bear an accessible alkyne group which can be directly attached to the cobalt center of $\mathrm{Cbl}$ following a copper-mediated reaction as described by Gryko and coworkers. ${ }^{[33]}$ Two bispyridyl ruthenium(II) complexes were chosen and adapted to the need of this coupling reaction: a cytotoxic compound, which was previously reported to accumulate at the plasma membranes of ovarian carcinoma cell line A2780, $\left[\mathrm{Ru}(\mathrm{NNbpy})_{3}\right]^{2+}$ (where NNbpy = diethylamino-2,2'-bipyridine) and the standard $\left[\mathrm{Ru}(\mathrm{bpy})_{3}\right]^{2+}$ (bipy: 2,2'bipyridine). ${ }^{[34]}$ These two compounds were synthetized asymmetrically in order to substitute one of the original bipyridyl ligands by a 4-ethynyl-2,2'-bipyridine ligand ( $\mathrm{C} \equiv \mathrm{Cbpy}$ ), as previously reported to give $\left[\mathrm{Ru}(\mathrm{NNbpy})_{2}(\mathrm{C} \equiv \mathrm{Cbpy})\right]^{2+}(\mathbf{1})$ and $\left[\mathrm{Ru}(\mathrm{bpy})_{2}(\mathrm{C} \equiv \mathrm{Cbpy})\right]^{2+}(\mathbf{2})$ as shown in Figure 1. ${ }^{[35,36]}$

Ruthenium complexes
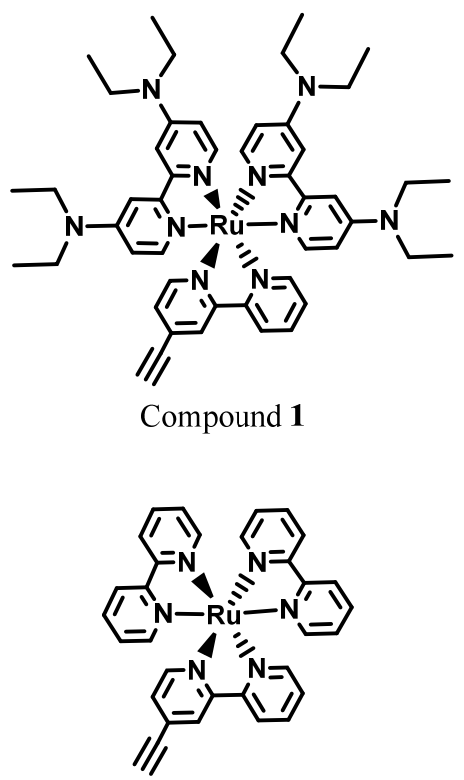

Compound 2
B12 conjugates

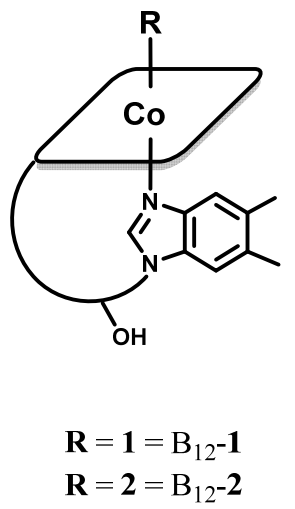

Figure 1. Ruthenium complexes and $\mathrm{B}_{12}$ conjugates used in this study. 
The complexes $\mathbf{1}$ and $\mathbf{2}$ were then coupled to cobalamin in good yield by adapting Gryko's procedure $^{[31]}$ to give two $\mathrm{B}_{12}$ derivatives: $\mathrm{B}_{12}-\mathbf{1}$ and $\mathrm{B}_{12}-2$ (see Figure 1). The compounds were unambiguously characterized by ${ }^{1} \mathrm{H}$ NMR and HR-ESI-MS and their purity verified by HPLC (see ESI). Very importantly, all compounds were found stable in water for at least 7 days as well as light stable over the same time period.

\section{Photophysical properties}

With both compounds in hand, we investigated their photophysical properties to evaluate their potential as PDT PSs (Tables 1 and 2). As a first experiment, the absorption of the compounds was measured in $\mathrm{MeOH}$ and compared with their $\mathrm{B}_{12}$-conjugates (Image 2). Since the necessary ${ }^{3}$ MLCT band centered at $450 \mathrm{~nm}$ did not significantly change, we assume that the photophysical properties of the conjugate should not be influenced through the conjugation. As a second experiment, the emission of the compounds was investigated upon excitation at $450 \mathrm{~nm}$ in $\mathrm{CH}_{3} \mathrm{CN}$. Compound 2 has an emission maximum at $635 \mathrm{~nm}$ and a luminescence quantum yield of 0.02 . These values are in the same range as other $\mathrm{Ru}(\mathrm{II})$ polypyridine complexes. ${ }^{[37,38]}$ However, the emission of $\mathbf{1}$ was barely measurable with the apparatus in our laboratory. As a third experiment, the luminescence lifetimes were determined and their influence on the presence of air investigated. Due to the very low emission of complex 1, its lifetime was not detected. This contrasts with the lifetime of compound $\mathbf{2}$ which was found to be in the same range than other $\mathrm{Ru}(\mathrm{II})$ polypyridyl complexes. ${ }^{[37,38]}$ Importantly, the excited state lifetime changed drastically upon the presence of oxygen indicating that ${ }^{3} \mathrm{O}_{2}$ is able to interact with the excited state of 2 .

Table 1. Photophysical properties of $\mathbf{1}$ and 2. $\lambda_{\mathrm{abs}}=$ absorption maximum in $\mathrm{MeOH}, \lambda_{\mathrm{em}}=$ emission maximum in $\mathrm{CH}_{3} \mathrm{CN}, \Phi_{\mathrm{em}}=$ luminescence quantum yield in $\mathrm{CH}_{3} \mathrm{CN}, \tau=$ luminescence lifetime, n.d. = not detectable.

\begin{tabular}{lllll}
\hline Compound & $\boldsymbol{\lambda}_{\mathrm{em}} / \mathbf{n m}$ & $\boldsymbol{\Phi}_{\mathrm{em}}$ & $\boldsymbol{\tau} / \mathbf{n s}$ & \\
\hline $\mathbf{1}$ & & & air & degassed \\
$\mathbf{2}$ & 695 & $>0.001$ & n.d. & n.d. \\
\hline
\end{tabular}

After showing that our compounds are able to interact with oxygen, we investigated quantitatively the production of singlet oxygen $\left({ }^{1} \mathrm{O}_{2}\right)$ upon light exposure. This is a crucial 
factor for a PS since ${ }^{1} \mathrm{O}_{2}$ is known to be the major active species for most applied PSs in the clinics. For this purpose, two different methods have been used: 1) direct by measurement of the phosphorescence of ${ }^{1} \mathrm{O}_{2}, 2$ ) indirect by measurement of the change in absorbance of a reporter molecule. ${ }^{[39]}$ Worthy of note, only singlet oxygen quantum yields over $20 \%$ can be detected via the direct method with our apparatus. The results shown in Table 2 demonstrate that compounds $\mathbf{1}$ and $\mathbf{2}$ are producing ${ }^{1} \mathrm{O}_{2}$ only poorly. This could be explained by the weak population of the excited state indicated by the poor luminescence properties of the complexes (Table 1) which is a necessary requirement for the production of ${ }^{1} \mathrm{O}_{2}$.

Table 2. Singlet oxygen quantum yields in $\mathrm{CH}_{3} \mathrm{CN}$ and aqueous solution determined at 450 $\mathrm{nm}$. Average of three independent measurements.

\begin{tabular}{lll}
\hline Compound & $\begin{array}{l}\text { Indirect 450 } \\
\text { nm } \mathbf{C H}_{3} \mathbf{C N}\end{array}$ & $\begin{array}{l}\text { Indirect 450 } \\
\text { nm PBS }\end{array}$ \\
\hline $\mathbf{1}$ & $8 \%$ & $3 \%$ \\
$\mathbf{2}$ & $19 \%$ & $7 \%$ \\
\hline
\end{tabular}

\section{Evaluation of PDT activity}

Dark and light cytotoxicity of the complexes was investigated in the cervical cancer cell line (HeLa) and non-cancerous retina pigmented epithelium (RPE-1) cell lines. It was expected that the $\mathrm{B} 12$ derivatives would be more toxic to both cell lines due to the presence of $\mathrm{B}_{12}$ that should increase their uptake. Surprisingly, compound 2 and its derivative B12-2 showed no cytotoxicity both in the dark or upon light irradiation. On the contrary, complex 1 was found to be cytotoxic in the dark ( $\mathrm{IC}_{50}: 9.33 \pm 1.43 \mu \mathrm{M}$ and $6.08 \pm 0.085 \mu \mathrm{M}$ on HeLa and RPE-1 cell lines,

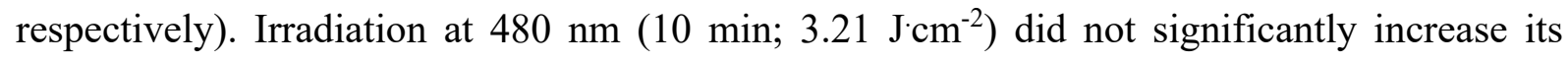
toxicity. Photoindex (PI) values ( $\mathrm{IC}_{50}$ dark/IC 50 light) of 1.3 and 1.1 for Hela and RPE-1 cell lines, respectively, were determined. To our surprise, the $\mathrm{B}_{12}-\mathbf{1}$ complex was found to be not toxic in the dark. Light irradiation of cells treated with $\mathrm{B}_{12}-\mathbf{1}$ did not caused toxicity in the RPE1 cell line or in the HeLa cell line (see results in Table 1). Overall, these studies did not show any correlation between the presence of vit $\mathrm{B}_{12}$ and (photo-)toxicity, clearly emphasizing that the coupling of $\mathrm{Cbl}$ was not helping in the delivery of our $\mathrm{Ru}(\mathrm{II})$ complexes. An obvious reason could be the bulkiness of the $\mathrm{Ru}(\mathrm{II})$ complexes. In a more general context, these disappointing results highlight the difficulty in specifically delivering metal complexes to cancer cells. 
Table 3. IC 50 values of complexes incubated with RPE-1 or HeLa cell line in the dark and upon light irradiation (in $\mu \mathrm{M}$ ).

Compound Cell line

RPE-1

HeLa

\begin{tabular}{ccccccc} 
& Dark & Light & PI value & Dark & Light & PI value \\
\hline $\mathbf{1}$ & $6.08 \pm$ & $5.43 \pm$ & 1.1 & $9.33 \pm$ & $7.14 \pm$ & 1.3 \\
& 0.085 & 0.060 & & 1.43 & 0.13 & \\
$\mathrm{~B}_{12-1}$ & $>100$ & $>100$ & - & $>100$ & $>100$ & - \\
$\mathbf{2}$ & $>100$ & $>100$ & - & $>100$ & $>100$ & - \\
$\mathrm{B}_{12-2}$ & $>50$ & $>50$ & - & $>50$ & $>50$ & - \\
\hline
\end{tabular}

$\mathrm{Ru}(\mathrm{II})$ polypyridyl complexes are usually known to be highly luminescent. ${ }^{[40]}$ We have therefore used this characteristic to further investigate the cellular biodistribution of the complexes in cells, and confocal microscopy studies were performed. Disappointingly, these two $\mathrm{Ru}(\mathrm{II})$ complexes as well as their $\mathrm{B}_{12}$ derivatives showed very weak or no luminescent signal in treated HeLa cells (see Fig S13). For this reason, cellular localisation could not be precisely determined, although localization in the cytoplasm could be faintly observed.

\section{Conclusions}

In this article, we have presented the evaluation of trisbipyridyl $\mathrm{Ru}(\mathrm{II})$ complexes $\mathbf{1}$ and $\mathbf{2}$ conjugated with vitamin $\mathrm{B}_{12}$ as potential photosensitisers for PDT. The conjugation with cobalamin increased the water solubility of the compounds, especially for complex $\mathbf{1}$ which was found to be extremely poorly soluble in this solvent. Unfortunately, our rutheniumcontaining conjugates were found to not have any significant phototoxic activity to the cell lines studied in this work. In addition, we could not precisely determine the cellular localization of the complexes by confocal microscopy due to either the lack of luminescence of the $\mathrm{Ru}$ (II) complexes or due to the very poor uptake of the compounds. Overall, this study suggests that the transcobalamin pathway is unlikely involved for the uptake of our $\mathrm{Ru}(\mathrm{II})$ conjugates. It would be interesting to assess if this is true with other $\mathrm{Ru}(\mathrm{II})$ polypyridyl complexes.

\section{Experimental Section}




\section{General experimental details}

All chemicals were purchased from Sigma-Aldrich (St Louis, MO) and used without further purification. The ligand 4-ethynyl-2,2'-bipyridine was synthesized according to a published procedure as well as the Ru complexes $\mathbf{1}$ and $\mathbf{2}$ and the $\mathrm{B}_{12}$ derivative $\mathrm{B}_{12}-\mathbf{1} .^{15,16}$ HPLC analyses were performed on a Merck-Hitachi L7000. The analytical separations were conducted on a Macherey-Nagel Nucleodur PolarTec column (5 $\mu$ m particle size, $110 \AA$ pore size, $250 \times 3$ $\mathrm{mm})$. The preparative separations were conducted on a Macherey-Nagel Nucleodur C18 HTec column $(5 \mu \mathrm{m}$ particle size, $110 \AA \AA$ pore size, $250 \times 21 \mathrm{~mm})$. HPLC solvents were water $(\mathrm{A})$ and methanol (B). The compounds were separated using the following gradient: $0-5 \mathrm{~min}(75 \%$ solvent A), 5-35 (75\% solvent $\mathrm{A} \rightarrow 0 \%$ solvent $\mathrm{A}), 35-45 \mathrm{~min}$ (100\% solvent $\mathrm{B})$. The flow rate was set to $0.5 \mathrm{ml}^{*} \mathrm{~min}^{-1}$ for analytical separations and $5 \mathrm{ml}^{*} \mathrm{~min}^{-1}$ for the preparative ones. The eluting bands were detected at $320 \mathrm{~nm}$. High resolution ESI-MS was performed on a Bruker FTMS 4.7-T Apex II (positive mode) and the UV/Vis spectra recorded on a Jasco V-730. NMR analyses were recorded on a Bruker Avance III $500 \mathrm{MHz}$. The corresponding ${ }^{1} \mathrm{H}$ and ${ }^{13} \mathrm{C}$ chemical shifts are reported relative to residual solvent protons and carbons.

\section{Synthesis and characterization of the derivative $B_{12}-2$}

The following procedure was adapted from the literature to achieve the synthesis of the $\mathrm{B}_{12}$ derivatives. ${ }^{13}$ A mixture of cyanocobalamin (20 mg, $0.013 \mathrm{mmol}, 1$ eq.), CuAcO (2.3 mg, $0.0013 \mathrm{mmol}, 0.1$ eq.) and the alkynes 2 (0.07 mmol, 5 eq.) in DMA (3.5 ml) was stirred until dissolution. DBU $(0.01 \mathrm{ml}, 0.7 \mathrm{mmol}, 5$ eq.) was added and the solution was allowed to react at room temperature for $4 \mathrm{~h}$. The respective crudes were precipitated by dropwise addition to a stirred solution of diethyl ether/ $\mathrm{CH}_{2} \mathrm{Cl}_{2}(50 \mathrm{ml}, 1: 1)$. The residue was dissolved in a mixture of $\mathrm{CH}_{3} \mathrm{OH}$ and water $(2 \mathrm{ml}, 1: 1)$, filtered again and purified by preparative HPLC. The eluting band containing the desired product was isolated and lyophilized.

B12-2: Isolated as a brownish powder, yield $19.8 \mathrm{mg}$ (70\%). ${ }^{\mathbf{1}} \mathbf{H}$ NMR (500 MHz, MeOD-[d4]): $\delta=8.53(\mathrm{t}, \mathrm{J}=9.5 \mathrm{~Hz}, 4 \mathrm{H}), 8.25(\mathrm{t}, \mathrm{J}=9.37 \mathrm{~Hz}, 1 \mathrm{H}), 8.09-7.99(\mathrm{~m}, 5 \mathrm{H}), 7.85-7.69(\mathrm{~m}, 6 \mathrm{H})$, $7.54(\mathrm{dd}, \mathrm{J}=6.0,2.37 \mathrm{~Hz}, 1 \mathrm{H}), 7.40-7.32(\mathrm{~m}, 5 \mathrm{H}), 7.29(\mathrm{~s}, 1 \mathrm{H}), 7.14(\mathrm{~s}, 1 \mathrm{H}), 6.82-6.76(\mathrm{~m}, 1 \mathrm{H})$, $6.50(\mathrm{~s}, 1 \mathrm{H}), 6.37$ (d, J = 3.2 Hz, 1H), 6.05 (d, J = 3.8 Hz, 1H), 4.38-4.23 (m, 2H), 4.13-4.07 $(\mathrm{m}, 1 \mathrm{H}), 3.95(\mathrm{dd}, \mathrm{J}=13.0,2.45 \mathrm{~Hz}, 1 \mathrm{H}), 3.78(\mathrm{dd}, \mathrm{J}=13.0,4.0 \mathrm{~Hz}, 2 \mathrm{H}), 3.62$ (d, J = 14.3 Hz, 1H), 3.43-3.35 (m, 2H), 3.32-3.25 (m, 2H), 2.99 (dd, J = 9.0, $5.3 \mathrm{~Hz}, 2 \mathrm{H}), 2.79-2.32(\mathrm{~m}, 16 \mathrm{H})$, $2.27(\mathrm{~s}, 6 \mathrm{H}), 2.14(\mathrm{t}, \mathrm{J}=12.0,1 \mathrm{H}), 2.09-1.93(\mathrm{~m}, 7 \mathrm{H}), 1.89-1.77(\mathrm{~m}, 5 \mathrm{H}), 1.45(\mathrm{~d}, \mathrm{~J}=4.2 \mathrm{~Hz}$, $3 \mathrm{H}), 1.40(\mathrm{~d}, \mathrm{~J}=3.4 \mathrm{~Hz}, 3 \mathrm{H}), 1.34(\mathrm{~s}, 3 \mathrm{H}), 1.27$ (d, J = 6.3 Hz, 3H), 1.18 (s, 1H), 1.15 (s, 3H), 1.13-1.02 (m, 2H), $0.52(\mathrm{~s}, 3 \mathrm{H}) \mathrm{ppm}$; UV/Vis spectrum in methanol solution: $\lambda_{\max }=330,363$, 
460, 519, 552; HPLC: $\mathrm{t}_{\mathrm{R}}=14.5 \mathrm{~min}$; HR-ESI-MS $\left(\mathrm{ESI}^{+}\right):[\mathrm{M}]^{2+}=960.8315$, calculated for $\mathrm{C}_{94} \mathrm{H}_{111} \mathrm{Co}_{11} \mathrm{~N}_{19} \mathrm{O}_{14} \mathrm{P}_{1} \mathrm{Ru}_{1}=960.8342$.

\section{Cell culture}

HeLa cell line was cultured in DMEM (Gibco, Life Technologies, USA) supplemented with $10 \%$ of fetal calf serum (Gibco). RPE-1 cell were cultured in DMEM/F-12 (Gibco) supplemented with $10 \%$ of fetal calf serum. Cell lines were complemented with $100 \mathrm{U} / \mathrm{ml}$ penicillin-streptomycin mixture (Gibco), and maintained in humidified atmosphere at $37^{\circ} \mathrm{C}$ and $5 \%$ of $\mathrm{CO}_{2}$.

\section{Cytotoxicity studies}

Dark and light cytotoxicity of the Ru(II) complexes and $\mathrm{Ru}(\mathrm{II})$ conjugates was assesed by fluorometric cell viability assay using resazurin (ACROS Organics). For light and dark cytotoxicity, HeLa and RPE-1 cells were seeded in triplicates in 96 well plates at a density of 4000 cells per well in $100 \mu \mathrm{l}, 24 \mathrm{~h}$ prior to treatment. Cells were then treated with increasing concentration of compounds for $48 \mathrm{~h}$. After that time medium was replaced by fresh complete medium. For light cytotoxicity experiments HeLa and RPE-1 cells were exposed to $480 \mathrm{~nm}$ light for $10 \mathrm{~min}$ in a 96-well plate using a LUMOS-BIO photoreactor (Atlas Photonics). Each well was individually illuminated with a $5 \mathrm{~lm}$ LED at constant current (light dose $3.21 \mathrm{~J} \mathrm{~cm}^{-2}$ ). After $44 \mathrm{~h}$ in the incubator medium was replaced by fresh complete medium containing resazurin $\left(0.2 \mathrm{mg} \mathrm{ml}^{-1}\right.$ final concentration). After $4 \mathrm{~h}$ incubation at $37^{\circ} \mathrm{C}$, fluorescence signal of resorufin product was read by SpectraMax M5 mictroplate reader (ex: $540 \mathrm{~nm}$; em: $590 \mathrm{~nm}$ ). $\mathrm{IC}_{50}$ values were calculated using GraphPad Prism software.

\section{Localisation studies}

Cellular localisation of the $\mathrm{Ru}(\mathrm{II})$ compounds was assessed by fluorescent microscopy. HeLa cells were grown on the $12 \mathrm{~mm}$ Menzel-Gläser coverslips in $2 \mathrm{ml}$ of complete medium at a density of $1.3 \times 10^{5}$ cells per ml. Cells were then treated with the compounds (IC50 concentration in the dark) for $2 \mathrm{~h}$, with NucBlue ( 2 drops per $1 \mathrm{ml}$ of media) for the last $25 \mathrm{~min}$ and with 100 nm Mitotracker Green FM for the last $15 \mathrm{~min}$. HeLa cells were then fixed with paraformaldehyde solution in PBS (4\%) and mounted on glass slides using Prolong Glass Antifade Mountant. Leica SP8 confocal microscope was used to analyse the samples. Ru compounds were excited at $488 \mathrm{~nm}$ and emission above $650 \mathrm{~nm}$ was recorded. Images were 
recorded in Cellular and Molecular Imaging Technical Platform, INSERM UMS 025 - CNRS

UMS 3612, Faculty of Pharmacy of Paris, Paris Descartes University, Paris, France.

\section{Supplementary Material}

Supporting information for this article is available on the WWW under http://dx.doi.org/10.1002/MS-number.

\section{Acknowledgements}

We gratefully acknowledge financial support from the ERC (Consolidator Grant PhotoMedMet (GA 681679) to G.G.) and the Swiss National Science Foundation (Grant\# PP00P2_170589). This work has received support under the program «Investissements d'Avenir » launched by the French Government and implemented by the ANR with the reference ANR-10-IDEX-000102 PSL (G.G.). We thank Dr. Philippe Goldner for access to a state-of-the-art laser apparatus.

\section{Author Contribution Statement}

M. J, J. R., J. K. and J. D. performed the experiments, analyzed the data and wrote the paper.

B. G., F. Z and G. G. conceived and designed the experiments.

\# these authors have contributed equally to the work.

\section{References}

[1] I. J. MacDonald, T. J. Dougherty, 'Basic principles of photodynamic therapy', $J$. Porphyr. Phthalocyanines 2001, 5, 105-129.

[2] C. Mari, V. Pierroz, S. Ferrari, G. Gasser, 'Combination of Ru(ii) complexes and light: new frontiers in cancer therapy', Chem. Sci. 2015, 6, 2660-2686.

[3] C. Lottner, K. C. Bart, G. Bernhardt, H. Brunner, 'Hematoporphyrin-derived soluble porphyrin-platinum conjugates with combined cytotoxic and phototoxic antitumor activity', J. Med. Chem. 2002, 45, 2064-2078.

[4] P. Agostinis, K. Berg, K. A. Cengel, T. H. Foster, A. W. Girotti, S. O. Gollnick, S. M. Hahn, M. R. Hamblin, A. Juzeniene, D. Kessel, M. Korbelik, J. Moan, P. Mroz, D. Nowis, J. Piette, B. C. Wilson, J. Golab, 'Photodynamic therapy of cancer: an update', CA: Cancer J. Clin. 2011, 61, 250-281.

[5] I. Yoon, J. Z. Li, Y. K. Shim, 'Advance in photosensitizers and light delivery for photodynamic therapy', Clin. Endosc. 2013, 46, 7-23.

[6] M. Jakubaszek, B. Goud, S. Ferrari, G. Gasser, 'Mechanisms of action of Ru(ii) polypyridyl complexes in living cells upon light irradiation', Chem. Commun. 2018, 54, 13040-13059.

[7] F. Heinemann, J. Karges, G. Gasser, 'Critical Overview of the Use of Ru(II) Polypyridyl Complexes as Photosensitizers in One-Photon and Two-Photon Photodynamic Therapy', Acc. Chem. Res. 2017, 50, 2727-2736. 
[8] L. Zeng, P. Gupta, Y. Chen, E. Wang, L. Ji, H. Chao, Z. S. Chen, 'The development of anticancer ruthenium(ii) complexes: from single molecule compounds to nanomaterials', Chem. Soc. Rev. 2017, 46, 5771-5804.

[9] L. K. McKenzie, H. E. Bryant, J. A. Weinstein, 'Transition metal complexes as photosensitisers in one- and two-photon photodynamic therapy', Coordin. Chem. Rev. 2019, 379, 2-29.

[10] S. Monro, K. L. Colon, H. Yin, J. Roque, 3rd, P. Konda, S. Gujar, R. P. Thummel, L. Lilge, C. G. Cameron, S. A. McFarland, 'Transition Metal Complexes and Photodynamic Therapy from a Tumor-Centered Approach: Challenges, Opportunities, and Highlights from the Development of TLD1433', Chem. Rev. 2018.

[11] J. Hess, H. Huang, A. Kaiser, V. Pierroz, O. Blacque, H. Chao, G. Gasser, 'Evaluation of the Medicinal Potential of Two Ruthenium(II) Polypyridine Complexes as Oneand Two-Photon Photodynamic Therapy Photosensitizers', Chemistry 2017, 23, 98889896.

[12] Y. Chen, R. L. Guan, C. Zhang, J. J. Huang, L. N. Ji, H. Chao, 'Two-photon luminescent metal complexes for bioimaging and cancer phototherapy', Coordin. Chem. Rev. 2016, 310, 16-40.

[13] H. Huang, B. Yu, P. Zhang, J. Huang, Y. Chen, G. Gasser, L. Ji, H. Chao, 'Highly Charged Ruthenium(II) Polypyridyl Complexes as Lysosome-Localized Photosensitizers for Two-Photon Photodynamic Therapy', Angew. Chem. Int. Ed. Engl. 2015, 54, 14049-14052.

[14] S. Chakrabortty, B. K. Agrawalla, A. Stumper, N. M. Vegi, S. Fischer, C. Reichardt, M. Kogler, B. Dietzek, M. Feuring-Buske, C. Buske, S. Rau, T. Weil, 'Mitochondria Targeted Protein-Ruthenium Photosensitizer for Efficient Photodynamic Applications', J. Am. Chem. Soc. 2017, 139, 2512-2519.

[15] T. Wang, N. Zabarska, Y. Wu, M. Lamla, S. Fischer, K. Monczak, D. Y. Ng, S. Rau, T. Weil, 'Receptor selective ruthenium-somatostatin photosensitizer for cancer targeted photodynamic applications', Chem. Commun. 2015, 51, 12552-12555.

[16] X. Zhao, M. Li, W. Sun, J. Fan, J. Du, X. Peng, 'An estrogen receptor targeted ruthenium complex as a two-photon photodynamic therapy agent for breast cancer cells', Chem. Commun. 2018, 54, 7038-7041.

[17] E. Villemin, Y. C. Ong, C. M. Thomas, G. Gasser, 'Polymer encapsulation of ruthenium complexes for biological and medicinal applications', Nat. Rev. Chem. 2019, 3, 261-282.

[18] Y. Ellahioui, M. Patra, C. Mari, R. Kaabi, J. Karges, G. Gasser, S. Gomez-Ruiz, 'Mesoporous silica nanoparticles functionalised with a photoactive ruthenium(ii) complex: exploring the formulation of a metal-based photodynamic therapy photosensitiser', Dalton Trans. 2018.

[19] M. Appold, C. Mari, C. Lederle, J. Elbert, C. Schmidt, I. Ott, B. Stuhn, G. Gasser, M. Gallei, 'Multi-stimuli responsive block copolymers as a smart release platform for a polypyridyl ruthenium complex', Polym. Chem. 2017, 8, 890-900.

[20] R. Green, L. H. Allen, A. L. Bjorke-Monsen, A. Brito, J. L. Gueant, J. W. Miller, A. M. Molloy, E. Nexo, S. Stabler, B. H. Toh, P. M. Ueland, C. Yajnik, 'Vitamin B12 deficiency', Nat. Rev. Dis. Primers 2017, 3, 17040.

[21] A. J. Wierzba, S. Hassan, D. Gryko, 'Synthetic Approaches toward Vitamin B12 Conjugates', Asian J. Org. Chem. 2019, 8, 6-24.

[22] F. Zelder, 'Recent trends in the development of vitamin B12 derivatives for medicinal applications', Chem. Commun. 2015, 51, 14004-14017. 
[23] A. Pettenuzzo, R. Pigot, L. Ronconi, 'Vitamin B-12-Metal Conjugates for Targeted Chemotherapy and Diagnosis: Current Status and Future Prospects', Eur. J. Inorg. Chem. 2017, 1625-1638.

[24] J. Delasoie, J. Rossier, L. Haeni, B. Rothen-Rutishauser, F. Zobi, 'Slow-targeted release of a ruthenium anticancer agent from vitamin B12 functionalized marine diatom microalgae', Dalton Trans. 2018, 47, 17221-17232.

[25] C. Lottner, K. C. Bart, G. Bernhardt, H. Brunner, 'Soluble tetraarylporphyrin-platinum conjugates as cytotoxic and phototoxic antitumor agents', J. Med. Chem. 2002, 45, 2079-2089.

[26] F. Schmitt, P. Govindaswamy, G. Suss-Fink, W. H. Ang, P. J. Dyson, L. JuilleratJeanneret, B. Therrien, 'Ruthenium porphyrin compounds for photodynamic therapy of cancer', J. Med. Chem. 2008, 51, 1811-1816.

[27] C. Mari, V. Pierroz, R. Rubbiani, M. Patra, J. Hess, B. Spingler, L. Oehninger, J. Schur, I. Ott, L. Salassa, S. Ferrari, G. Gasser, 'DNA intercalating Ru(II) polypyridyl complexes as effective photosensitizers in photodynamic therapy', Chemistry 2014, 20, 14421-14436.

[28] B. Krautler, 'Vitamin B12: chemistry and biochemistry', Biochem. Soc. Trans. 2005, 33, 806-810.

[29] E. Nexø, Cobalamin Binding Proteins, Jon Wiley \& Sons, 2007.

[30] K. L. Brown, 'Chemistry and enzymology of vitamin B-12', Chem. Rev. 2005, 105, 2075-2149.

[31] B. Krautler, 'Organometallic chemistry of b(12) coenzymes', Met. Ions Life Sci. 2009, 6, 1-51.

[32] M. Ruetz, R. Salchner, K. Wurst, S. Fedosov, B. Krautler, 'Phenylethynylcobalamin: a light-stable and thermolysis-resistant organometallic vitamin $\mathrm{B}(12)$ derivative prepared by radical synthesis', Angew. Chem. Int. Ed. Engl. 2013, 52, 11406-11409.

[33] M. Chrominski, A. Lewalska, D. Gryko, 'Reduction-free synthesis of stable acetylide cobalamins', Chem. Commun. 2013, 49, 11406-11408.

[34] O. Zava, S. M. Zakeeruddin, C. Danelon, H. Vogel, M. Gratzel, P. J. Dyson, 'A cytotoxic ruthenium tris(bipyridyl) complex that accumulates at plasma membranes', Chembiochem 2009, 10, 1796-1800.

[35] J. Rossier, D. Hauser, E. Kottelat, B. Rothen-Rutishauser, F. Zobi, 'Organometallic cobalamin anticancer derivatives for targeted prodrug delivery via transcobalaminmediated uptake', Dalton Trans. 2017, 46, 2159-2164.

[36] C. Herrero, A. Quaranta, S. El Ghachtouli, B. Vauzeilles, W. Leibl, A. Aukauloo, 'Carbon dioxide reduction via light activation of a ruthenium-Ni(cyclam) complex', Phys. Chem. Chem. Phys. 2014, 16, 12067-12072.

[37] M. J. Cook, A. P. Lewis, G. S. G. Mcauliffe, V. Skarda, A. J. Thomson, J. L. Glasper, D. J. Robbins, 'Luminescent Metal-Complexes .1. Tris-Chelates of Substituted 2,2'Bipyridyls with Ruthenium(Ii) as Dyes for Luminescent Solar Collectors', J. Chem. Soc. Perk. T. 2 1984, 1293-1301.

[38] A. Juris, V. Balzani, F. Barigelletti, S. Campagna, P. Belser, A. Vonzelewsky, 'Ru(Ii) Polypyridine Complexes - Photophysics, Photochemistry, Electrochemistry, and Chemi-Luminescence', Coordin. Chem. Rev. 1988, 84, 85-277.

[39] J. Karges, P. Goldner, G. Gasser, 'Synthesis, Characterization, and Biological Evaluation of Red-Absorbing Fe(II) Polypyridine Complexes', Inorganics 2019, 7.

[40] V. Fernandez-Moreira, F. L. Thorp-Greenwood, M. P. Coogan, 'Application of d6 transition metal complexes in fluorescence cell imaging', Chem. Commun. 2010, 46, 186-202. 